\title{
Utilization of Rooftop Solar Units to Generate Electricity and Hydrogen: A Technoeconomic Analysis
}

\author{
Mostafa Rezaei $\left(\mathbb{D},{ }^{1}\right.$ Mehdi Jahangiri $\mathbb{C D}^{2},{ }^{2}$ and Armin Razmjoo ${ }^{3}$ \\ ${ }^{1}$ Queensland Micro- and Nanotechnology Centre, Griffith University, Nathan 4111, QLD, Australia \\ ${ }^{2}$ Department of Mechanical Engineering, Shahrekord Branch, Islamic Azad University, Shahrekord, Iran \\ ${ }^{3}$ Escola Técnica Superior d'Énginyeria Industrial de Barcelona (ETSEIB), Universitat Politécnica de Catalunya (UPC), Av. Diagonal, \\ 647, 08028 Barcelona, Spain
}

Correspondence should be addressed to Mehdi Jahangiri; jahangiri.m@iaushk.ac.ir

Received 13 July 2021; Revised 4 September 2021; Accepted 6 October 2021; Published 9 November 2021

Academic Editor: Philippe Poggi

Copyright (C) 2021 Mostafa Rezaei et al. This is an open access article distributed under the Creative Commons Attribution License, which permits unrestricted use, distribution, and reproduction in any medium, provided the original work is properly cited.

\begin{abstract}
This study is aimed at scrutinizing the domestic solar energy potential for electricity and hydrogen production. Under the first scenario, it is sought to evaluate electricity generation for household purposes using RSUs (rooftop solar units). Then, under the second scenario, solar hydrogen production is analyzed for the purpose of meeting a hydrogen vehicle demand. For this, one of the aptest cities, Yazd, located in the center of Iran is investigated. Furthermore, a real-world electric load needed by an usual household in Yazd is deemed as the demand for electricity. To analyze the two scenarios, a system consisting of an $8.2 \mathrm{~kW}$ RSU for power generation, a battery for electricity storage, and a $1 \mathrm{~kW}$ electrolyzer for hydrogen yield is proposed. Also, to acquire a broader vision, predictions are made for the next 10, 20,30, and 40 years. The results regarding the first scenario implied that COE (Cost of Electricity) would be, respectively, 0.067, 0.145, 0.136, and $0.127 \$ / \mathrm{kWh}$. In addition to supplying the electricity required by the house, 2,687 $\$$ /yr could be earned by selling the excess electricity generated, and $5,759 \mathrm{~kg}$ of $\mathrm{CO}_{2}$ would be avoided a year. The findings as to the second scenario showed that LCOH (levelized cost of hydrogen) would equate to $3.62,6.53,6.34$, and $5.93 \$ / \mathrm{kg}$, respectively, for the aforementioned project lifetimes. Furthermore, $2,464 \$ / y r$ would be the revenue after selling the surplus electricity, and 7,820 $\mathrm{kg}$ of $\mathrm{CO}_{2}$ would be saved, annually.
\end{abstract}

\section{Introduction}

Solar energy is being freely released every day in countless parts of the world, and a great portion of this environmentally sustainable energy is lost without being exploited. This invaluable energy resource like other renewable means cannot be retained in its original form for being used in the future. As a result, converting it into electricity and consequently keeping the surplus amount in electrical storages for later usage is one of the most practical and effective methods of harnessing solar energy. This transition can occur via the application and installation of PV (Photovoltaic) systems wherever solar irradiance reaches.

1.1. Motivation and Incitement. Solar energy has long grasped attention of developing and developed countries due to its noteworthy advantages. The major merits are ease of exploitation, abundance, lower imposed costs compared to other means, and appropriateness for urban and country environment $[1,2]$. In spite of the fact that solar power generation sites with high capacities have been constructed in suitable areas around the world, domestic-scale ones have not satisfactorily developed, mostly in nonindustrialized countries. Lack of solid research and scientific evidence has considerably contributed to this issue. Thus, the aforementioned reason can well fuel the idea of conducting a study on domestic solar power generation especially in a developing country.

1.2. Literature Review. Iryna et al. [3] performed a study to assess the solar energy promotion in the household sector of Sumy that is lain in the northeastern area of Ukraine. 
As the economic aspect of any project is of high importance, the main focus of the study was on the projection of financial sustainability of solar PV power generation plants. The findings indicated that the profitability of the understudy projects would be high for the both schemes of own and credit resources' investment. The results of the calculations revealed that the $10 \mathrm{~kW}$ and $30 \mathrm{~kW}$ solar plants would reach different levels of profitability, respectively, $78.91 \%$ and 128.04\%. Carroquino et al. [4] conducted a research to investigate the utilization of solar energy for generating electricity and hydrogen at Viñas del Vero winery, placed in the Somontano region in the north of Aragon, Spain. The solarbased electricity was arranged to be applied as power source for the wastewater treatment plant and the pumping station of the irrigation system. The results implied that $72 \mathrm{MWh}$ of electricity and $1,214 \mathrm{~m}^{3}$ of hydrogen could be obtained during the first year leading to saving 27 tons of $\mathrm{CO}_{2}$. Atiz et al. [5] examined electricity and hydrogen production by employing the approaches of evacuated tube solar collectors, a salt gradient solar pond, and an Organic Rankine Cycle in the city of Adana in southern Turkey. Using Engineering Equations Solver software, the results revealed that the energy and exergy efficiencies were, respectively, 5.92\% and $18.21 \%$. Also, hydrogen production ratio would become $3.2 \mathrm{~kg}$ per day. Samsatli et al. [6] proposed, designed, and optimized an electricity and hydrogen production system using wind power in order to supply energy required by the domestic transportation sector in Great Britain. Geographical Information System (GIS) was used to ascertain the most suitable areas for the construction of wind sites while considering 10 technical and environmental constraints. The calculations found that all the demand for energy could be met via onshore wind. Duman and Güler [7] investigated the viability of harnessing wind and solar energy in order to supply electricity for vacation homes during summer days, in Çeşme, İzmir, Turkey. HOMER simulations indicated that $\mathrm{COE}$ of offgrid hybrid renewable energy systems would be higher than that of the grid. Ishaq et al. [8] carried out a study to assess the performance of a wind-powered electricity generation system to supply energy for a community of households in Toronto, Canada. The surplus electricity was assumed to be utilized for hydrogen production which later could be used in the fuel cells to overcome the issue of power shortage in periods of low wind speeds. The results showed that energy and exergy efficiencies were, respectively, equal to $20.2 \%$ and $21.2 \%$ when wind velocity was $5 \mathrm{~m} / \mathrm{s}$. Nyholm et al. [9] developed and analyzed a model for using batteries in domestic PV systems in Sweden. The results suggested that adding batteries within the range of 0.15 to $100 \mathrm{kWh}$ can raise the level of selfconsumption by 20 to $50 \%$. Regarding the matter of convincing residents of dwellings/houses to apply renewable resources for power generation, Perera et al. [10] evaluated and introduced some incentivizing schemes for using clean energy in household sector considering economic and environmental aspects in various provinces of Canada. Rahut et al. [11] attempted to determine the factors impacting on the choice of solar energy for household utilization in three African countries of Ethiopia, Tanzania, and Uganda. The household size, the number of residents, and the level of education and wealth were introduced as the key criteria in selecting solar energy. Narayan et al. [12] sought to optimize the sizing process of solar home systems in order to minimize the loss of load probability, battery size, and excess electricity dump while maximizing battery lifetime. To this end, a multiobjective genetic algorithm was deployed for optimally sizing the components using the data for an Indian city in the tropical regions. Hosseini et al. [13] conducted a research to examine the viability of hydrogen utilization as a battery in a solar power plant on rooftops. This hydrogen was to be acquired by the excess electricity generated via the RSUs. It was then sent to a fuel cell system to make electricity needed by the load at nights. Jahangiri et al. [14] performed a technical, economic, and environmental analysis for a grid-connected wind/solar power generation plant in 25 remote towns of Chad. It was also assumed that the surplus energy would be used for hydrogen production. In this regard, cost-competitive models were developed and assessed by HOMER software. Maleki et al. [15] introduced and analyzed a hybrid solar/wind/hydrogen powered desalination system for providing potable water demanded by the remote area of Davarzan, Khorasan, Iran. The life cycle cost assessment and the likelihood of loss of power supply constituted for optimizing the system using artificial bee swarm optimization. Moreover, Jahangiri et al. [16] studied the feasibility of using solar and wind energy for generating electricity and hydrogen in the south of Iran, the city of Bandar Abbas. To serve the purpose of their study, three scenarios including (I) grid-connected wind power plant, (II) grid-connected solar power plant, and (III) grid-connected hybrid solar/wind power plant were scrutinized using HOMER software. Akhtari and Baneshi [17] performed a technoeconomic analysis in order to evaluate the feasibility of utilizing an offgrid hybrid wind/solar/diesel generator/boiler system for the purpose of cogenerating electricity, heat, and hydrogen to meet required load by major cities of Bandar Abbas, Shiraz, Tabriz, Tehran, and Yazd in Iran. The excess electricity was used to make thermal energy via an electric boiler. Applying HOMER software, the findings showed that deploying the surplus electric power could result in improving renewable fraction by $35 \%$ and declining $\mathrm{COE}$ and $\mathrm{CO}_{2}$ emissions by $7.1 \%$ and $10.6 \%$, respectively.

Surveying the literature related to the subject of this study, ample studies have been conducted to investigate electricity and hydrogen generation using renewables, but just several examined domestic solar electricity generation, and none studied the utilization of offgrid RSUs to make hydrogen for domestic transport purpose in Iran.

1.3. Existing Research Gap and Novelty. Having surveyed the related literature, it has been spotted that Iran lacks a comprehensive research work in relation to the construction of a domestic-size solar power generation plant in order to make electricity for (I) meeting the electric load demanded by an individual house or for (II) producing hydrogen for refueling a hydrogen or fuel cell vehicle. To fill the gap, this study is performed to investigate the potential of 
implementing PV systems on rooftop of a house in an appropriate city for the purpose of supplying all electricity required by the house or utilizing it to generate hydrogen. As to novelty, this is the first study therein a domestic solar-powered hydrogen generation plant is proposed and evaluated to meet the household demand for hydrogen in Iran.

1.4. Objectives. The main objectives of the study are as follows:

(i) Assessing the potential of solar energy for domestic electrification

(ii) Investigating the technical and economic viability of hydrogen production using the solar electricity

(iii) Projecting the economic aspects including PBP (payback period) and annual incomes of selling the excess solar electricity

1.5. Paper Structure. The rest of this work is as follows: case study area is briefly discussed in Section 2. Third section includes material, components, and methods. Assumptions and scenarios are demonstrated in Section 4, and finally, analysis and conclusion are drawn in Sections 5 and 6, respectively.

\section{Case Study Area}

Owing to the location of Iran lain near the Earth's Sun Belt, the country receives a significant amount of solar energy in its most areas [18]. Among many suitable places of Iran in terms of enjoying solar energy, Yazd situated in the middle of Iran possesses substantial solar potential. The city has long sunny days, rough 13 hours, in summers which make it an appropriate candidate for solar energy exploitation [19]. Hence, Yazd is chosen as the case study, and its position in the solar radiation map of Iran is demonstrated in Figure 1.

It should be noted that residents of Yazd mostly use electricity just for cooling purposes like air conditioning in hot days of year and for supplying some kitchen appliances, such as refrigerator, dishwasher, and washing machine, with energy. Other equipment such as heating and cooking devices in Yazd's houses is gas-consuming.

\section{Materials, Components, and Methods}

To design and analyze the proposed solar power plant, HOMER pro software is utilized. This tool is a fast-running, applicable, and trustworthy computer-based system which has proved being capable of simulating, modeling, sizing, and optimizing hybrid renewable power generation systems. The software also deploys the average of long-term data gathered by NASA [20], and this makes the results more realistic.

\subsection{System Components}

3.1.1. Rooftop Solar Units. The main part of a solar power plant is PV panel which transforms solar irradiance into electricity. To set this apparatus in the proposed system in
HOEMR, first, it should be clarified whether the output of the RSUs is AC (alternating current) or DC (direct current). If it is $\mathrm{AC}$, then specifications of an inverter including its lifetime, efficiency, and costs are required; otherwise, those of a MPPT (maximum power point tracker) should be set. To obtain the most precise results, HOMER software has introduced some advanced options like GR (ground reflectance), TS (tracking system), PS (panel slope), and PA (panel azimuth). Afterwards, the lifetime and size of the RSUs should be determined along with its derating factor. The latter is factored into the calculations to simulate real-world conditions by which the output of the units degrades. Setting all the aforementioned parameters, the power output of the RSUs is computed by Eq. (1) [21, 22].

$$
P_{\mathrm{RSU}}=Y_{\mathrm{RSU}} f_{\mathrm{RSU}}\left(\frac{\bar{G}_{T}}{\bar{G}_{T, \mathrm{STC}}}\right)\left[1+\alpha_{p}\left(T_{C}-T_{C, \mathrm{STC}}\right)\right],
$$

in which $Y_{\mathrm{RSU}}$ denotes the nominal output of the RSU under standard environment in $\mathrm{kW}$ which is available on the technical sheet and $f_{\mathrm{RSU}}$ refers to derating factor in percent. $\bar{G}_{T}$ and $\bar{G}_{T, \text { STC }}$ are, respectively, the solar radiation reaching on the surface of the units and the radiation at standard test conditions in $\mathrm{kW} / \mathrm{m}^{2} . \alpha_{p}$ means the temperature coefficient of power in percent $/{ }^{\circ} \mathrm{C}$. $T_{C}$ and $T_{C, S T C}$, respectively, refer to the temperature of the PV cell in the current time step and that under standard test environment in ${ }^{\circ} \mathrm{C} . \bar{G}_{T}$ is obtained by Eq. (2) [23].

$$
\begin{aligned}
\bar{G}_{T}= & \left(\bar{G}_{b}+\bar{G}_{d}\left(\frac{\bar{G}_{b}}{\bar{G}_{o}}\right)\right)\left(\frac{\cos \theta}{\cos \theta_{z}}\right) \\
& +\bar{G}_{d}\left(1-\left(\frac{\bar{G}_{b}}{\bar{G}_{o}}\right)\right)\left(\frac{1+\cos \beta}{2}\right)\left[1+f \sin ^{3}\left(\frac{\beta}{2}\right)\right] \\
& +\left(\bar{G}_{b}+\bar{G}_{d}\right) \rho_{g}\left(\frac{1-\cos \beta}{2}\right),
\end{aligned}
$$

where $\bar{G}_{b}, \bar{G}_{d}$, and $\bar{G}_{o}$ are, respectively, the beam radiation, the diffuse radiation, and the mean extraterrestrial horizontal radiation. $\theta$ denotes the angle between the sun's beam radiation and the normal to the surface. $\theta_{z}$ and $\beta$ refer to the zenith angle and the slope of the surface, respectively. $f$ denotes a factor that is applied to account for horizon brightening. In other words, more diffuse radiation comes from the horizon in comparison with the rest of the sky; as such, this parameter is related to the cloudiness. $\rho_{g}$ is the ground reflectance, known as albedo.

3.1.2. Converter. Since the solar power plant contains AC and DC elements, therefore, it requires a converter. This device is basically included in the system to convert electricity from DC to AC during a process named inversion and also from AC to DC within a process called rectification [24]. As such, HOMER software allows to set two types of inputs for this component, one for inverter and the other for rectifier. The parameters related to the former are 


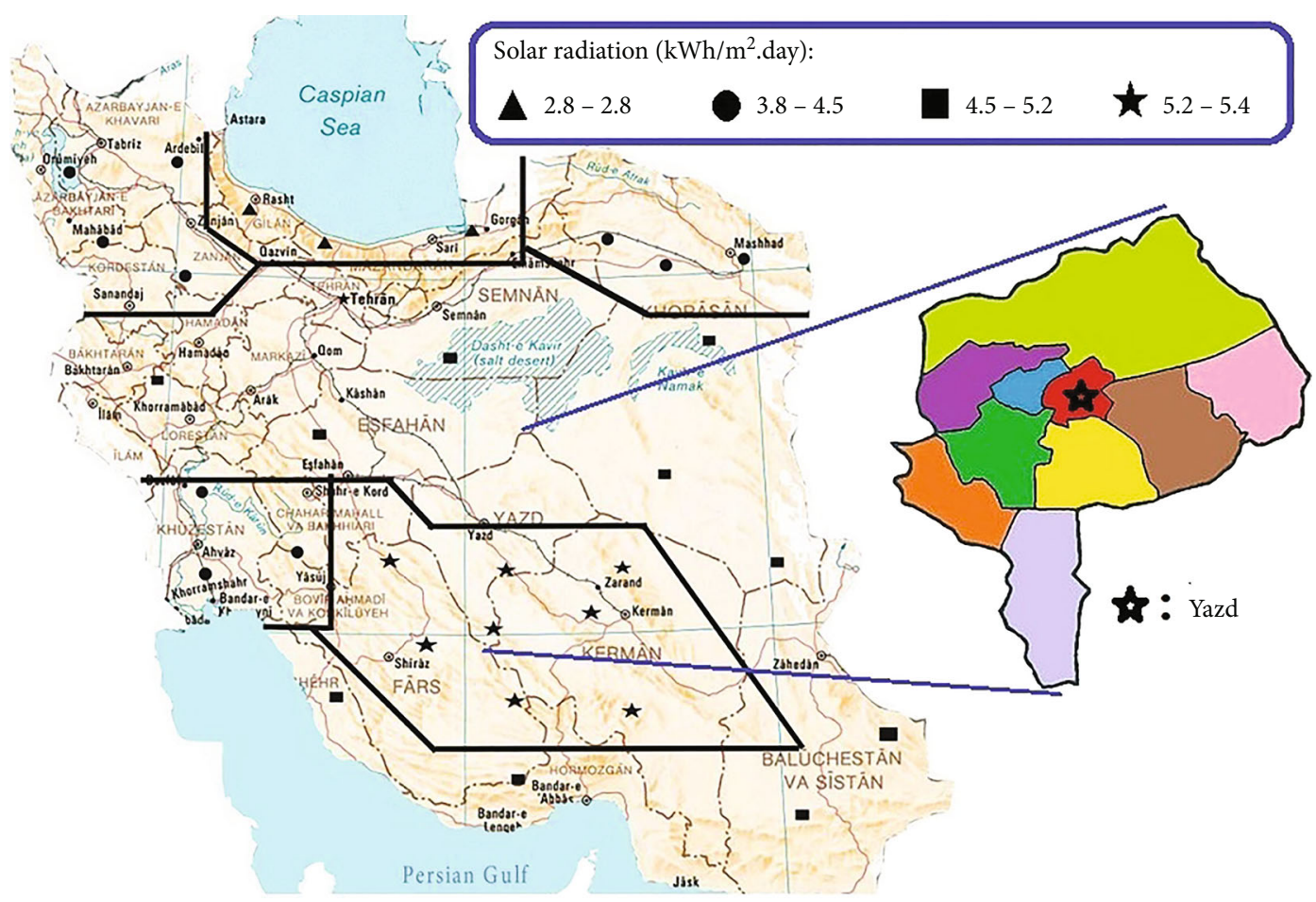

Figure 1: The location of Yazd Province and Yazd City in the solar radiation map of Iran.

TABle 1: Technical and economic specifications of the components.

\begin{tabular}{|c|c|c|c|c|c|c|}
\hline Component & Size/number & Lifetime (yr) & Capital cost & Replacement cost & $\mathrm{O} \& \mathrm{M}$ cost & Other characteristics \\
\hline RSUs & $8.2(\mathrm{~kW})$ & 25 & $1,560(\$ / \mathrm{kW})$ & $1,530(\$ / \mathrm{kW})$ & 10 (\$/kW.yr) & $\begin{array}{c}\text { Electrical bus: } \mathrm{AC} \\
\text { Derating factor: } 96 \% \\
\text { Temperature coefficient: }-0.41\left(\% /{ }^{\circ} \mathrm{C}\right) \\
\text { Operating temperature: } 45\left({ }^{\circ} \mathrm{C}\right) \\
\text { Efficiency: } 17.3 \% \\
\text { Ground reflectance: } 20 \% \\
\text { Tracking system: no tracking }\end{array}$ \\
\hline Converter & $1(\mathrm{~kW})$ & 15 & $600(\$ / \mathrm{kW})$ & $600(\$ / \mathrm{kW})$ & 10 (\$/kW.yr) & $\begin{array}{c}\text { Rectifier efficiency: } 90 \% \\
\text { Inverter efficiency: } 95 \% \\
\text { Rectifier relative capacity: } 100 \%\end{array}$ \\
\hline Storage & $1(\#)$ & 10 & $3,200(\$ / \#)$ & $3,000(\$ / \#)$ & 20 (\$/\#.yr) & $\begin{array}{c}\text { Throughput: } 80,000(\mathrm{kWh}) \\
\text { Nominal voltage: } 240(\mathrm{~V}) \\
\text { Nominal capacity: } 8(\mathrm{kWh}) \\
\text { Nominal capacity: } 33.3(\mathrm{ah}) \\
\text { Roundtrip efficiency: } 86 \% \\
\text { Maximum charge current: } 15(\mathrm{~A}) \\
\text { Maximum discharge current: } 15(\mathrm{~A}) \\
\text { Initial state of charge: } 100 \%\end{array}$ \\
\hline Electrolyzer & $1(\mathrm{~kW})$ & 15 & $1,450(\$ / \mathrm{kW})$ & $1,450(\$ / \mathrm{kW})$ & 60 (\$/kW.yr) & $\begin{array}{c}\text { Electrical bus: DC } \\
\text { Efficiency: } 85 \% \\
\text { Minimum load ratio: } 55 \%\end{array}$ \\
\hline Hydrogen tank & $20(\mathrm{~kg})$ & 25 & $120(\$ / \mathrm{kg})$ & $120(\$ / \mathrm{kg})$ & 5 (\$/kg.yr) & Initial tank level: 0 \\
\hline
\end{tabular}

lifetime and efficiency, and those concerned with the latter are relative capacity and efficiency.

3.1.3. Battery. As solar irradiance is not available during the whole day, hence, it should be turned into electricity and then stored in batteries. By virtue of this, the load does not suffer from energy shortage. To include an electricity storage in the solar power plant, there are four main parameters to set, capacity, initial state of charge, and minimum state of charge and lifetime. The latter should be determined by two values: one is time in years, and the other is throughput in $\mathrm{kWh}$. 


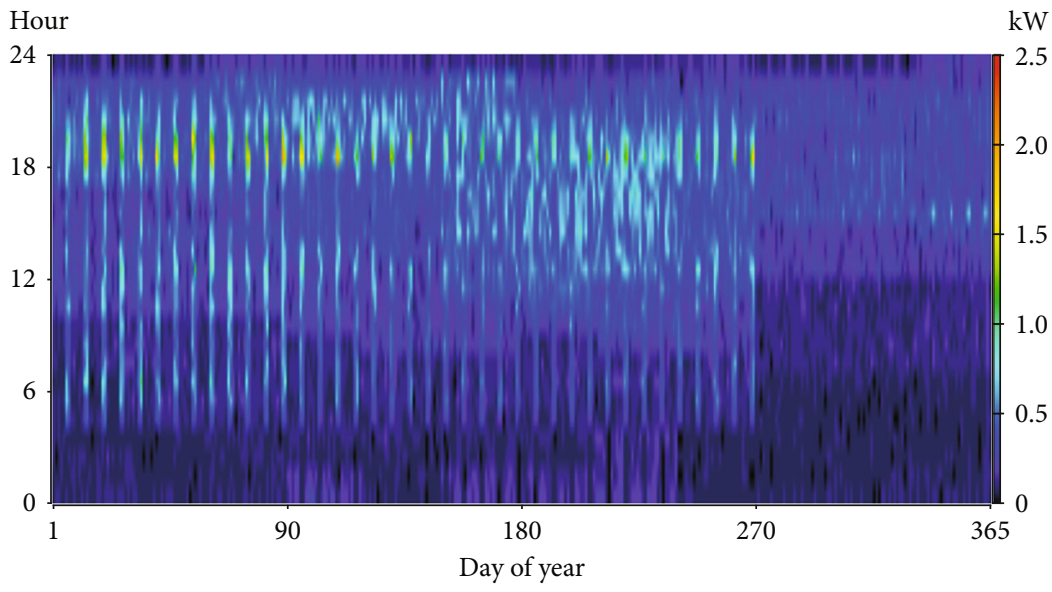

FIgURE 2: The load assumed to be required by the house in Yazd in an hourly basis [34].

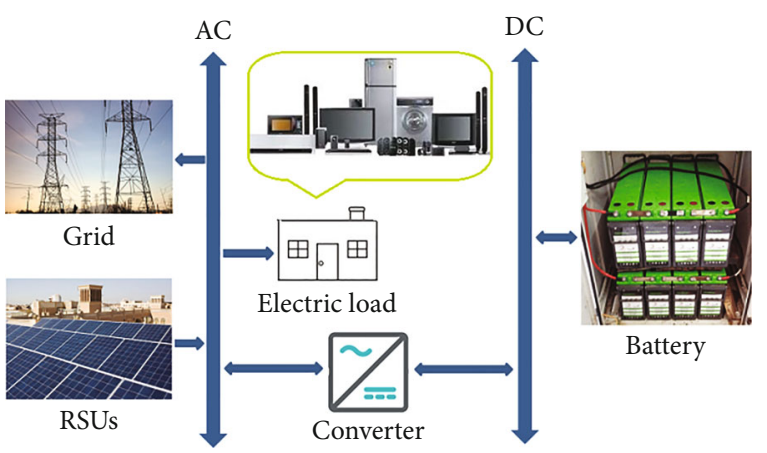

(a)

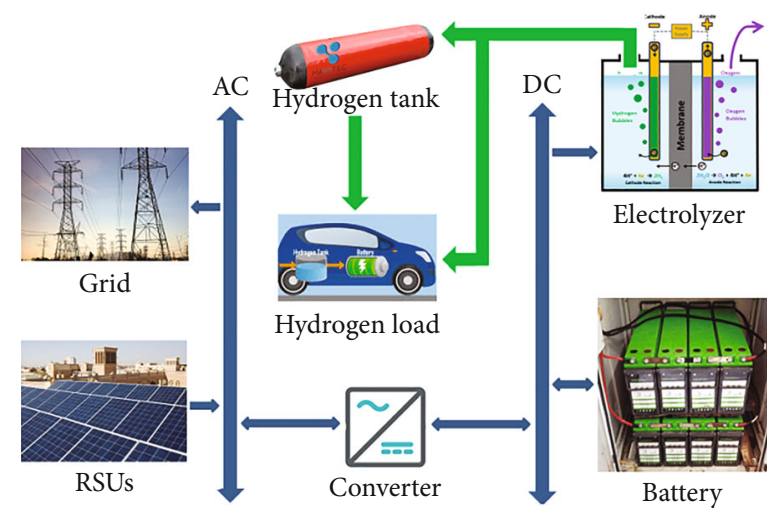

(b)

FIgURE 3: Schematic of the solar system to generate (a) electricity and (b) hydrogen.

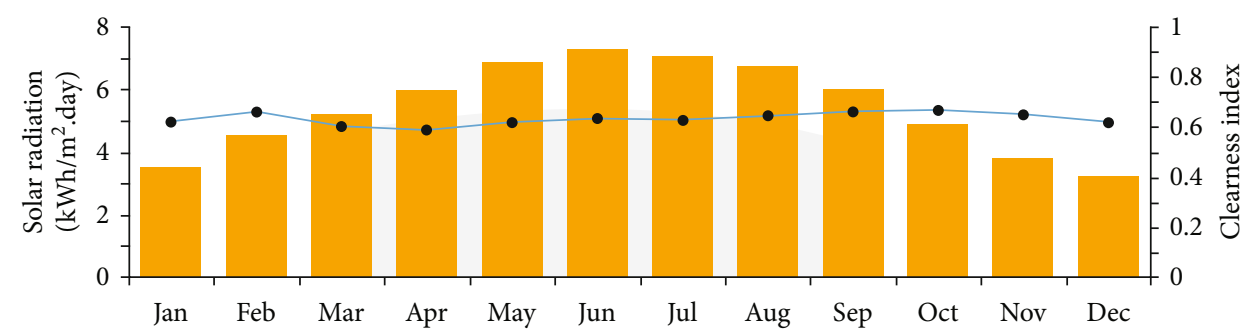

FIGURE 4: Solar radiation and clearness index pertaining to the city of Yazd.

TABle 2: Technical and economic analysis of the proposed system under scenario 1.

\begin{tabular}{|c|c|c|c|c|c|c|c|c|c|c|}
\hline $\begin{array}{l}\text { Project } \\
\text { lifetime }\end{array}$ & $\begin{array}{c}\mathrm{COE} \\
(\$ / \mathrm{kWh})\end{array}$ & $\begin{array}{c}\text { NPC } \\
(\$)\end{array}$ & $\begin{array}{l}\text { Operating } \\
\text { cost }(\$ / y r)\end{array}$ & $\begin{array}{l}\text { Initial } \\
\text { capital } \\
(\$)\end{array}$ & $\begin{array}{l}\text { Annualized } \\
\text { O \& M } \\
(\$ / y r)\end{array}$ & $\begin{array}{c}\text { Excess } \\
\text { electricity } \\
(\mathrm{kWh} / \mathrm{yr})\end{array}$ & $\begin{array}{l}\text { Revenue by selling } \\
\text { the excess electricity } \\
(\$ / y r)\end{array}$ & $\begin{array}{l}\text { Total electricity } \\
\text { production } \\
(\mathrm{kWh} / \mathrm{yr})\end{array}$ & $\begin{array}{l}\text { PBP } \\
(y r)\end{array}$ & $\begin{array}{l}\mathrm{CO}_{2} \text { emission } \\
\text { reduction } \\
(\mathrm{kg} / \mathrm{yr})\end{array}$ \\
\hline 10 & 0.067 & 2,680 & -927 & 16,592 & 112 & 17,680 & 2,687 & 20,792 & 1 & 5,759 \\
\hline 20 & 0.145 & 17,594 & 22 & 16,592 & 112 & 17,680 & 2,687 & 20,792 & 6.8 & 5,759 \\
\hline 30 & 0.136 & 38,603 & 207 & 16,592 & 112 & 17,680 & 2,687 & 20,792 & 15 & 5,759 \\
\hline 40 & 0.127 & 77,945 & 267 & 16,592 & 112 & 17,680 & 2,687 & 20,792 & 30.3 & 5,759 \\
\hline
\end{tabular}

3.1.4. Electrolyzer. The required specifications for simulating electrolyzer in the hydrogen production system are size, lifetime, efficiency, minimum load ratio, and electrical bus. In this regard, minimum load ratio means the least amount of power by which the nominated electrolyzer can operate properly. Moreover, electrical bus establishes whether the 
TABLe 3: Present worth and annualized value of all costs over 10 years.

\begin{tabular}{|c|c|c|c|c|c|c|c|c|c|c|}
\hline \multirow{2}{*}{ Component } & \multicolumn{5}{|c|}{ Net present costs $(\$)$} & \multicolumn{5}{|c|}{ Annualized costs $(\$ / y r)$} \\
\hline & Capital & Replacement & $\mathrm{O} \& \mathrm{M}$ & Salvage & Total & Capital & Replacement & $\mathrm{O} \& \mathrm{M}$ & Salvage & Total \\
\hline PV array & 12,792 & 0 & 1,231 & $-15,190$ & $-1,167$ & 852 & 0 & 82 & $-1,012$ & -78 \\
\hline Storage & 3,200 & 0 & 300 & 0 & 3,500 & 213 & 0 & 20 & 0 & 233 \\
\hline Converter & 600 & 0 & 151 & -404 & 347 & 40 & 0 & 10 & -27 & 23 \\
\hline System & 16,592 & 0 & 1,682 & $-15,594$ & 2,680 & 1,105 & 0 & 112 & $-1,039$ & 178 \\
\hline
\end{tabular}

TABLE 4: Present worth and annualized value of all costs over 20 years.

\begin{tabular}{|c|c|c|c|c|c|c|c|c|c|c|}
\hline \multirow{2}{*}{ Component } & \multicolumn{5}{|c|}{ Net present costs $(\$)$} & \multicolumn{5}{|c|}{ Annualized costs (\$/yr) } \\
\hline & Capital & Replacement & $\mathrm{O} \& \mathrm{M}$ & Salvage & Total & Capital & Replacement & $\mathrm{O} \& \mathrm{M}$ & Salvage & Total \\
\hline PV array & 12,792 & 0 & 3,715 & $-10,217$ & 6,290 & 282 & 0 & 82 & -225 & 139 \\
\hline Storage & 3,200 & 6,054 & 906 & 0 & 10,160 & 71 & 134 & 20 & 0 & 225 \\
\hline Converter & 600 & 1,720 & 453 & $-1,629$ & 1,144 & 13 & 38 & 10 & -36 & 25 \\
\hline System & 16,592 & 7,774 & 5,074 & $-11,846$ & 17,594 & 366 & 172 & 112 & -261 & 389 \\
\hline
\end{tabular}

TABLE 5: Present worth and annualized value of all costs over 30 years.

\begin{tabular}{|c|c|c|c|c|c|c|c|c|c|c|}
\hline \multirow{2}{*}{ Component } & \multicolumn{5}{|c|}{ Net present costs $(\$)$} & \multicolumn{5}{|c|}{ Annualized costs $(\$ / y r)$} \\
\hline & Capital & Replacement & $\mathrm{O} \& \mathrm{M}$ & Salvage & Total & Capital & Replacement & $\mathrm{O} \& \mathrm{M}$ & Salvage & Total \\
\hline PV array & 12,792 & 72,567 & 8,728 & $-82,466$ & 11,621 & 120 & 682 & 82 & -775 & 109 \\
\hline Storage & 3,200 & 18,269 & 2,129 & 0 & 23,598 & 30 & 172 & 20 & 0 & 222 \\
\hline Converter & 600 & 1,720 & 1,064 & 0 & 3,384 & 6 & 16 & 10 & 0 & 32 \\
\hline System & 16,592 & 92,556 & 11,921 & $-82,466$ & 38,603 & 156 & 870 & 112 & -775 & 363 \\
\hline
\end{tabular}

TABLE 6: Present worth and annualized value of all costs over 40 years.

\begin{tabular}{|c|c|c|c|c|c|c|c|c|c|c|}
\hline \multirow{2}{*}{ Component } & \multicolumn{5}{|c|}{ Net present costs $(\$)$} & \multicolumn{5}{|c|}{ Annualized costs $(\$ / y r)$} \\
\hline & Capital & Replacement & $\mathrm{O} \& \mathrm{M}$ & Salvage & Total & Capital & Replacement & $\mathrm{O} \& \mathrm{M}$ & Salvage & Total \\
\hline PV array & 12,792 & 72,567 & 18,843 & $-83,203$ & 20,999 & 56 & 316 & 82 & -362 & 92 \\
\hline Storage & 3,200 & 42,918 & 4,596 & 0 & 50,714 & 14 & 187 & 20 & 0 & 221 \\
\hline Converter & 600 & 6,650 & 2,298 & $-3,316$ & 6,232 & 3 & 29 & 10 & -14 & 28 \\
\hline System & 16,592 & 122,135 & 25,737 & $-86,519$ & 77,945 & 73 & 532 & 112 & -376 & 341 \\
\hline
\end{tabular}

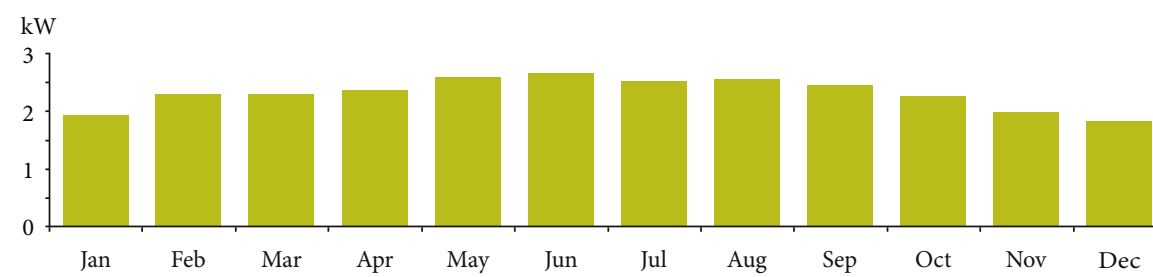

FIGURE 5: Monthly average electricity production via the under investigation RSUs.

electrolyzer consumes AC or DC power. To compute the output of the electrolyzer which is hydrogen, Eq. (3) can be applied [25].

$$
M_{\text {hydrogen }}=\frac{E_{\mathrm{RSU}}}{E_{\text {electrolyzer }}} \times \eta \text {, }
$$

where $\mathrm{M}_{\text {hydrogen }}$ indicates the mass of hydrogen gained annually. $E_{\mathrm{RSU}}$ denotes the yearly amount of electricity generated by the RSUs and sent to the input of the electrolyzer. $E_{\text {electrolyzer }}$ and $\eta$ are the amount of energy required by the electrolyzer and efficiency of which, respectively.

3.1.5. Hydrogen Storage. To proceed with the analysis of the solar-powered hydrogen production system, a hydrogen tank constitutes in the system for storing the excess 
hydrogen possibly generated by the electrolyzer. The required properties are size, initial tank level, and lifetime.

\subsection{Economic Aspect}

3.2.1. Coe. This value is an output variable which can be obtained by the economic analysis of the system. The software uses Eq. (4) to compute COE [26].

$$
\mathrm{COE}=\frac{C_{\mathrm{ann}, \text { tot }}}{E_{\mathrm{AC}}+E_{\mathrm{DC}}+E_{\mathrm{def}}+E_{\text {grid }}} .
$$

$C_{\text {ann,tot }}$ is the total annualized cost denoting the annualized value of the total NPC (net present cost), shown by Eq. (5) [27]. $E_{\mathrm{AC}}, E_{\mathrm{DC}}, E_{\mathrm{def}}$, and $E_{\text {grid }}$, respectively, refer to the amount of electricity produced and sent to serve the primary AC load, the primary DC load, the deferrable load, and the excess energy sold to the grid. It should be noted that HOMER considers a derating factor by which the amount of electricity produced via RSUs degrades year after year. In other words, this coefficient determines the reduction rate of the performance of solar units and how it degrades over the technical lifetime of the project.

$$
C_{\text {ann,tot }}=\left(\frac{(d-i / 1+i)(1+(d-i / 1+i))^{n}}{(1+(d-i / 1+i))^{n}-1}\right) C_{\text {NPC.tot }}
$$

where $d, i$, and $n$ are, respectively, nominal discount rate, expected inflation rate, and the project lifespan. $C_{\text {NPC.tot }}$ means the total NPC.

3.2.2. NPC. NPC can be acquired by subtracting the present value of all the revenues, comprising salvage value and incomes of selling renewable electricity, over the project lifetime from the present value of all the costs, including capital costs, replacement costs, operation and maintenance costs (OM), fuel costs, emission penalties, and the costs of purchasing power from the grid, incurred during the whole lifespan of the project. With regard to the costs, because an autonomous domestic-size solar power plant is investigated, so the costs related to fuel, emission penalties, and buying from the grid are not factored into the calculations.

3.2.3. $\mathrm{LCOH}$. To speculate the cost which would be incurred for producing a kg of hydrogen, called LCOH, Eq. (6) is used [28].

$$
\mathrm{LCOH}=\frac{C_{\mathrm{NPC}, \text { tot }}-R_{\text {electricity }}}{\sum M_{\text {hydrogen }}},
$$

in which $\sum M_{\text {hydrogen }}$ denotes the total amount of hydrogen that will be retained during the entire project lifetime and $R_{\text {electricity }}$ refers to the net present value of all revenues after selling the solar electricity.

3.2.4. Operating Cost. This output variable shows the annualized value of all costs incurred and incomes earned except for the initial capital costs. It can be projected by Eq. (7) [23].

$$
C_{\text {operating }}=C_{\text {ann,tot }}-C_{\text {ann,cap }} \text {, }
$$
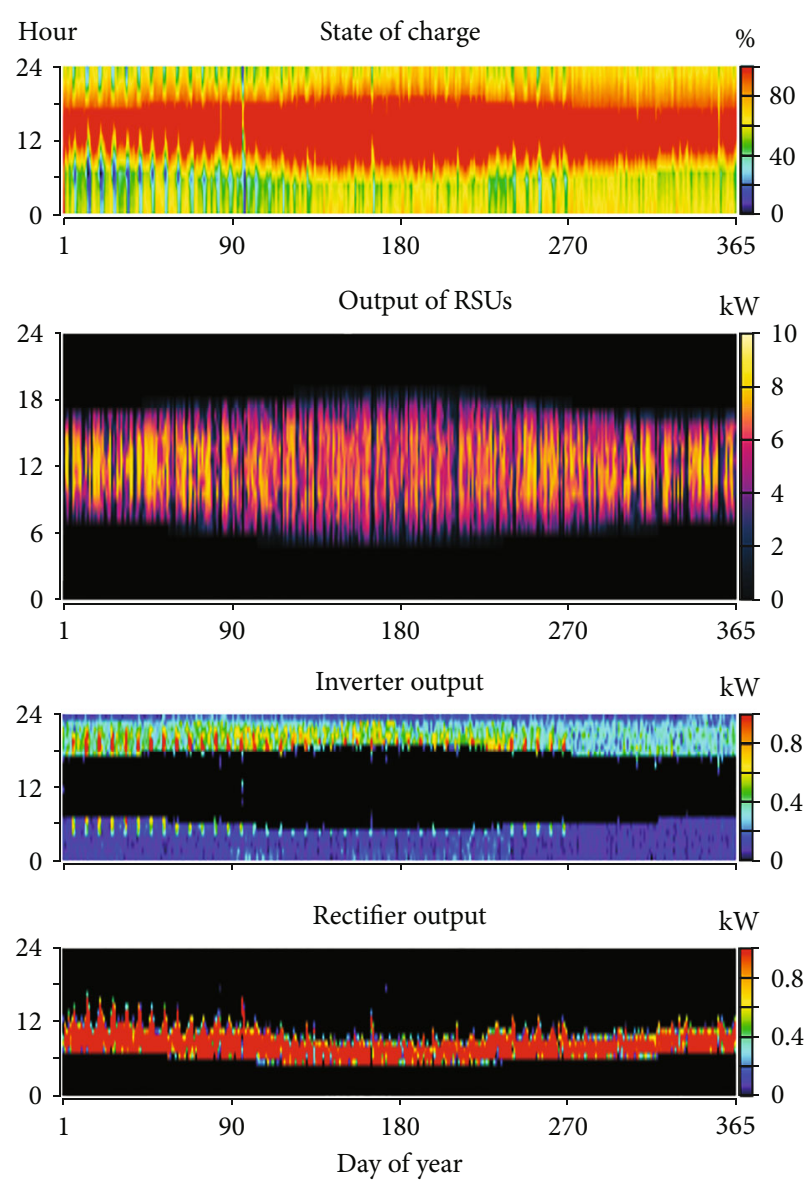

FIGURE 6: State of charge of the battery, power output of RSUs and system converter (including inverter output and rectifier output).

in which $C_{\text {ann,cap }}$ is the total annualized capital cost and is gained via Eq. (8).

$$
C_{\text {ann }, \text { cap }}=C_{\text {ini, } t} \times\left(\frac{(d-i / 1+i)(1+(d-i / 1+i))^{n}}{(1+(d-i / 1+i))^{n}-1}\right),
$$

where $C_{\text {ini, } t}$ denotes the total initial capital cost, that is, the summation of prices of all equipment necessary for the construction of the solar power or hydrogen generation plant.

3.2.5. PBP of Selling the Excess Electricity. To speculate the time required to reach profitability after selling the excess electricity to the grid, Eq. (9) can be used [29]. If the obtained values of PBP were lucrative and less than the project lifetime, then people of the city would be stimulated to invest on this project. In other words, PBP can be deemed as an added incentive in addition to supplying your own electricity and fuel.

$$
\mathrm{PBP}=\frac{\mathrm{NPC}}{\mathrm{RE}-\mathrm{OM}},
$$

where RE is the annualized revenue by selling the surplus energy, and OM refers to the annualized operation and maintenance cost. 
TABLE 7: Technical and economic analysis of the proposed system under scenario 2.

\begin{tabular}{|c|c|c|c|c|c|c|c|c|c|c|}
\hline $\begin{array}{l}\text { Project } \\
\text { lifetime }\end{array}$ & $\begin{array}{c}\mathrm{LCOH} \\
(\$ / \mathrm{kg})\end{array}$ & $\begin{array}{c}\text { NPC } \\
(\$)\end{array}$ & $\begin{array}{l}\text { Operating } \\
\text { cost }(\$ / y r)\end{array}$ & $\begin{array}{l}\text { Initial } \\
\text { capital } \\
(\$)\end{array}$ & $\begin{array}{l}\text { Annualized } \\
\text { O \& M } \\
(\$ / y r)\end{array}$ & $\begin{array}{c}\text { Excess } \\
\text { electricity } \\
(\mathrm{kWh} / \mathrm{yr})\end{array}$ & $\begin{array}{l}\text { Revenue by selling } \\
\text { the excess electricity } \\
\qquad \$ / y r)\end{array}$ & $\begin{array}{c}\text { Hydrogen } \\
\text { generation } \\
(\mathrm{kg} / \mathrm{yr})\end{array}$ & $\begin{array}{l}\text { PBP } \\
(y r)\end{array}$ & $\begin{array}{l}\mathrm{CO}_{2} \text { emission } \\
\text { reduction }(\mathrm{kg} / \\
\mathrm{yr})\end{array}$ \\
\hline 10 & 3.62 & 4,826 & $-1,040$ & 20,422 & 257 & 16,212 & 2,464 & 90 & 2.2 & $5,759+2,061$ \\
\hline 20 & 6.53 & 26,280 & 129 & 20,422 & 257 & 16,212 & 2,464 & 90 & 11.9 & $5,759+2,061$ \\
\hline 30 & 6.34 & 60,150 & 373 & 20,422 & 257 & 16,212 & 2,464 & 90 & 27.2 & $5,759+2,061$ \\
\hline 40 & 5.93 & 121,138 & 438 & 20,422 & 257 & 16,212 & 2,464 & 90 & 54.9 & $5,759+2,061$ \\
\hline
\end{tabular}

Note: the last column includes two numbers, the first one is for the amount of $\mathrm{CO}_{2}$ reduction resulted from solar electricity production, and the other is for that from hydrogen utilization as fuel.

TABLE 8: Present worth and annualized value of all costs over 10 years.

\begin{tabular}{|c|c|c|c|c|c|c|c|c|c|c|}
\hline \multirow{2}{*}{ Component } & \multicolumn{5}{|c|}{ Net present costs $(\$)$} & \multicolumn{5}{|c|}{ Annualized costs $(\$ / y r)$} \\
\hline & Capital & Replacement & $\mathrm{O} \& \mathrm{M}$ & Salvage & Total & Capital & Replacement & $\mathrm{O} \& \mathrm{M}$ & Salvage & Total \\
\hline PV array & 12,792 & 0 & 1,231 & $-15,190$ & $-1,167$ & 852 & 0 & 82 & $-1,012$ & -78 \\
\hline Electrolyzer & 1,450 & 0 & 901 & -975 & 1,376 & 96 & 0 & 60 & -65 & 91 \\
\hline Hydrogen tank & 2,400 & 0 & 1,501 & $-2,906$ & 995 & 160 & 0 & 100 & -193 & 67 \\
\hline Storage & 3,200 & 0 & 75 & 0 & 3,275 & 213 & 0 & 5 & 0 & 218 \\
\hline Converter & 600 & 0 & 150 & -404 & 346 & 40 & 0 & 10 & -27 & 23 \\
\hline System & 20,442 & 0 & 3,858 & $-19,475$ & 4,825 & 1,361 & 0 & 257 & $-1,297$ & 321 \\
\hline
\end{tabular}

\section{Assumptions and Scenarios}

To fulfill the purpose of the study, some basic terms and conditions should be postulated in order to obtain the most close-to-reality results. These assumptions, consisting in characteristics of the equipment and the current prices in the country, are presented in Table 1.

Due to the purpose of this study, it has been assumed that the proposed system would be installed and utilized on the rooftop of an ordinary house in Yazd City. Most household buildings in the city have just one story with almost 90 to $100 \mathrm{~m}^{2}$ rooftop. Owing to the constraint that each 10 to $12 \mathrm{~m}^{2}$ rooftop can be used for installation of $1 \mathrm{~kW}$ RSUs, therefore, it has been hypothesized that the size of the RSUs would be $8.2 \mathrm{~kW}$. In addition, the price of purchasing solar electricity by the government is $0.152 \$ / \mathrm{kWh}$, according to Iranian Renewable Energy and Energy Efficiency Organization [30]. Average nominal discount rate and expected inflation rate are presumed to be $10 \%$ and $18 \%$, respectively. To gain broader view regarding the future of the project, 4 periods of 10, 20, 30, and 40 years have been taken into consideration as the project lifetime. Furthermore, electricity distributed by the grid in Yazd is fuel oilbased which emit almost $0.277 \mathrm{~kg} / \mathrm{kWh}$ of $\mathrm{CO}_{2}$ into the environment [31]. Thus, generating renewable electricity would stem $\mathrm{CO}_{2}$ emission at the abovementioned ratio. According to [32], burning a liter of gasoline would result in releasing $2.29 \mathrm{~kg}$ of $\mathrm{CO}_{2}$. It has also been reported by [33] that a $\mathrm{kg}$ of hydrogen can run a car for approximately $100 \mathrm{~km}$ which is almost equal to 10 liters of gasoline (these numbers are just hypothetical and may change due to technological advancement or case by case.); so, utilizing a hydrogenfueled car can save $22.9 \mathrm{~kg}$ of $\mathrm{CO}_{2}$ per a $\mathrm{kg}$ of hydrogen burnt. Typically, a car is being run $12,000 \mathrm{~km}$ per year which means $90 \mathrm{~kg}$ of hydrogen is needed for a year. In addition to the domestic hydrogen load which is $90 \mathrm{~kg}$ per year, the electric load that the proposed system is supposed to feed is illustrated in Figure 2. According to Yazd's Electrical Distribution Company [34], the average electric load demand of an ordinary household/dwelling is approximately 7.39 $\mathrm{kWh}$ per day, and the peak demand reaches almost $2.09 \mathrm{~kW}$.

Finally, the two following scenarios are examined while considering 4 periods of 10,20,30, and 40 years as the project lifetime. Figure 3 contains the schematic of two systems referring to each scenario.

(I) Supplying electricity required by the electric load and selling the excess electricity to the grid

(II) Supplying electricity required by the hydrogen load and selling the excess electricity to the grid

\section{Analysis}

To analyze the system, long-term data concerning solar radiation and clearness index collected by NASA are used by the software (Figure 4). After considering all the aforementioned postulations, HOMER runs the proposed system to obtain the technical and economic results.

5.1. Scenario I. Under this scenario, the least amount of COE, $0.067 \$ / \mathrm{kWh}$, was predicted for the case when the project lifetime would be 10 years. According to Eqs. (4) and (5) and given the definition of NPC, this result was expected to be observed because after passing 10 years, major components of the system including RSUs, converter, electrolyzer, and hydrogen tank would have value and can be sold to gain revenue. Further, Table 2 demonstrates that NPC related to the case of 10 years lifetime is by far the least amount amongst other cases, and this is due to the high salvage value 
TABLE 9: Present worth and annualized value of all costs over 20 years.

\begin{tabular}{lcccccccccc}
\hline \multirow{2}{*}{ Component } & \multicolumn{4}{c}{ Net present costs $(\$)$} & \multicolumn{4}{c}{ Annualized costs $(\$ / y r)$} \\
& Capital & Replacement & O \& M & Salvage & Total & Capital & Replacement & O \& M & Salvage & Total \\
\hline PV array & 12,792 & 0 & 3,715 & $-10,217$ & 6,290 & 282 & 0 & 82 & -225 & 139 \\
Electrolyzer & 1,450 & 4,156 & 2,718 & $-3,936$ & 4,388 & 32 & 92 & 60 & -87 & 97 \\
Hydrogen tank & 2,400 & 0 & 4,531 & $-1,954$ & 4,977 & 53 & 0 & 100 & -43 & 110 \\
Storage & 3,200 & 6,054 & 227 & 0 & 9,481 & 71 & 134 & 5 & 0 & 210 \\
Converter & 600 & 1,720 & 453 & $-1,629$ & 1,144 & 13 & 38 & 10 & -36 & 25 \\
System & 20,442 & 11,930 & 11,644 & $-17,736$ & 26,280 & 451 & 264 & 257 & -391 & 581 \\
\hline
\end{tabular}

TABle 10: Present worth and annualized value of all costs over 30 years.

\begin{tabular}{|c|c|c|c|c|c|c|c|c|c|c|}
\hline \multirow{2}{*}{ Component } & \multicolumn{5}{|c|}{ Net present costs $(\$)$} & \multicolumn{5}{|c|}{ Annualized costs $(\$ / y r)$} \\
\hline & Capital & Replacement & $\mathrm{O} \& \mathrm{M}$ & Salvage & Total & Capital & Replacement & $\mathrm{O} \& \mathrm{M}$ & Salvage & Total \\
\hline PV array & 12,792 & 72,567 & 8,728 & $-82,466$ & 11,621 & 120 & 682 & 82 & -775 & 109 \\
\hline Electrolyzer & 1,450 & 4,156 & 6,387 & 0 & 11,993 & 14 & 39 & 60 & 0 & 113 \\
\hline Hydrogen tank & 2,400 & 13,882 & 10,644 & $-15,775$ & 11,151 & 23 & 130 & 100 & -148 & 105 \\
\hline Storage & 3,200 & 18,269 & 532 & 0 & 22,001 & 30 & 172 & 5 & 0 & 207 \\
\hline Converter & 600 & 1,720 & 1,065 & 0 & 3,385 & 6 & 16 & 10 & 0 & 32 \\
\hline System & 20,442 & 110,594 & 27,356 & $-98,241$ & 60,151 & 193 & 1,039 & 257 & -923 & 566 \\
\hline
\end{tabular}

TABLE 11: Present worth and annualized value of all costs over 40 years.

\begin{tabular}{|c|c|c|c|c|c|c|c|c|c|c|}
\hline \multirow{2}{*}{ Component } & \multicolumn{5}{|c|}{ Net present costs $(\$)$} & \multicolumn{5}{|c|}{ Annualized costs $(\$ / y r)$} \\
\hline & Capital & Replacement & $\mathrm{O} \& \mathrm{M}$ & Salvage & Total & Capital & Replacement & $\mathrm{O} \& \mathrm{M}$ & Salvage & Total \\
\hline PV array & 12,792 & 72,567 & 18,843 & $-83,203$ & 20,999 & 56 & 316 & 82 & -362 & 92 \\
\hline Electrolyzer & 1,450 & 16,070 & 13,788 & $-8,013$ & 23,295 & 6 & 70 & 60 & -35 & 101 \\
\hline Hydrogen tank & 2,400 & 13,882 & 22,980 & $-15,916$ & 23,346 & 11 & 60 & 100 & -69 & 102 \\
\hline Storage & 3,200 & 42,918 & 1,149 & 0 & 47,267 & 14 & 187 & 5 & 0 & 206 \\
\hline Converter & 600 & 6,650 & 2,298 & $-3,316$ & 6,232 & 3 & 29 & 10 & -14 & 28 \\
\hline System & 20,442 & 152,087 & 59,058 & $-110,448$ & 121,139 & 90 & 662 & 257 & -480 & 529 \\
\hline
\end{tabular}

of apparatus at the end of the project. The amount of this variable rose to $0.145,0.136$, and $0.127 \$ / \mathrm{kWh}$ when considering 20,30, and 40 years as the project lifespan, respectively. The calculations showed promising results regarding PBP of investing on such projects. Again, the case of 10 years lifetime saw the smallest period of time which would be required to reach the break-even point, and this is due to the least amount of NPC. Projection for the 20 years lifetime case implied that the domestic solar power plant would reach its profitability after 6.8 years. Comparing the cases of 10 years and 20 years, NPC of the 20 -year case is significantly higher than that of the 10-year one; therefore, compensating this cost would definitely take much more time rather than the shorter period case. Table 2 includes the results of utilizing the proposed system for the purpose of feeding the electric load and selling the surplus electricity.

Tables 3-6 provide present worth and annualized value of all costs under the cases when the project lifetimes are $10,20,30$, and 40 years.

Figure 5 illustrates the monthly average electricity generation via the under investigation RSUs. Additionally, Figure 6 shows the state of charge of the battery, power output of the RSUs, and system converter (including inverter

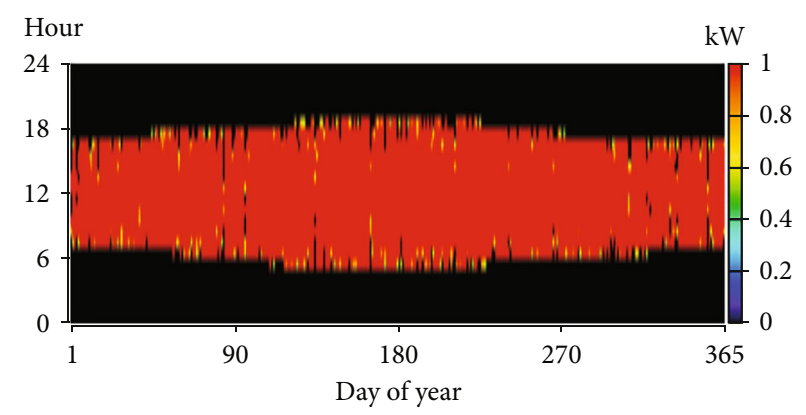

FIGURE 7: Electrolyzer input power.

output and rectifier output). The results revealed that capacity factor and mean output of the RSUs under this scenario would be $28.9 \%$ and $2.37 \mathrm{~kW}$, respectively. As expected, the battery would be fully charged during the hours of a day within which solar irradiance was available. Then, this stored energy could be used for the hours when output of the RSUs was almost zero.

5.2. Scenario II. Replacing the electric load with the hydrogen load, the solar-powered hydrogen production plant 


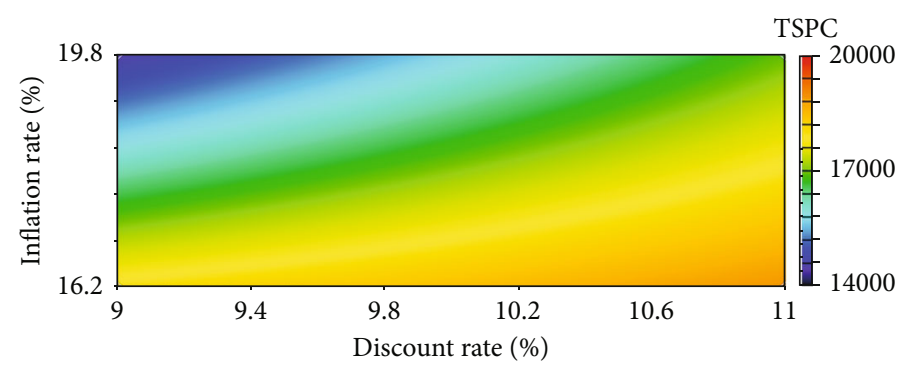

FIGURE 8: Surface plot of TNPC under scenario 1 with a 20 -year vision when considering a $\pm 10 \%$ fluctuation in discount and inflation rates.

was investigated for the purpose of generating $90 \mathrm{~kg}$ of hydrogen a year. This amount of hydrogen would be needed for feeding the car over a year to run $12,000 \mathrm{~km}$. Meanwhile, the excess electricity could be sold to the grid. Table $7 \mathrm{dem}$ onstrates the technoeconomic results of scrutinizing the aforementioned hydrogen production system in which PBP refers to the time of reaching break-even point after selling the excess electricity. It should be noted that the revenue of hydrogen was not factored into the calculations of PBP. The findings suggested that embarking on the project would only be lucrative if its lifespan were to be 10 or 20 years. Like scenario I, the reason behind observing the least amount of $\mathrm{LCOH}$ for the case of 10-year lifetime is that its NPC was computed to be the least in comparison with other project lifespans. This finally led to the smallest value for $\mathrm{LCOH}$ and the least period of time to obtain profit from the RSUs.

Tables 8-11 contain present worth and annualized value of all costs under different project lifetimes.

Figure 7 depicts the amount of power delivered to the electrolyzer. The results showed that capacity factor of and mean input power to the electrolyzer were, respectively, $47.1 \%$ and $0.471 \mathrm{~kW}$.

\section{Discussion}

Owing to the volatility of Iran's economy, the value of money significantly changes over time as inflation, and discount rates fluctuate. Apart from the reason behind the fluctuations, taking these prospective changes into consideration for any project is of utmost importance [35]. Also, due to the promising results of the first scenario, a sensitivity analysis was conducted to ascertain the impact of economic uncertainty on this scenario. Therefore, a $\pm 10 \%$ fluctuation in the both abovementioned rates was considered, and accordingly, its impact on TNPC (total bet present cost) of the first scenario was analyzed for the case of 20 years. It should be noted that because of the lifetime of the equipment associated with renewable electricity production, the most reasonable timeframe for renewable projects is a 20 -year vision. Figure 8 denotes surface plot of TNPC under scenario 1 with a 20 -year vision.

\section{Conclusion}

The imperative to decarbonize the energy sector has made it vital to assess the viability of utilizing renewable energies for domestic purposes. In this regard, solar energy-related equipment can be easily applied on the rooftops of houses in the appropriate areas. Thus, the purpose of this study was to propose and scrutinize a solar power generation system to provide electricity or hydrogen required for household purposes in Yazd, Iran. The technoeconomic analysis showed promising results which the main points are as follows:

(i) Installing the proposed solar power plant on the rooftop of an ordinary house in Yazd could result in generating $17,680 \mathrm{kWh} / \mathrm{yr}$ of electricity as the surplus electricity, in addition to meeting the electric power required by the house

(ii) Selling the excess electricity to the grid, the owner of the system could earn $\$ 2,687$ annually

(iii) Utilizing the proposed system under the first scenario could save approximately $5,759 \mathrm{~kg}$ of $\mathrm{CO}_{2}$ emissions per year

(iv) Selling the excess electricity to the grid, PBP of investing on solar electricity production would be $1,6.8,15$, and 30.3 years if the project lifetimes were $10,20,30$, and 40 years

(v) The least amount of $\mathrm{LCOH}$ would equal to $3.62 \$ / \mathrm{yr}$ when the project lifetime was 10 years. This case also would end up avoiding some $7,820 \mathrm{~kg}$ of $\mathrm{CO}_{2}$ emissions and earning $\$ 2,464$ per year after selling the surplus electricity

(vi) Under the provision of 30 and 40 years, setting up the hydrogen production system would not be plausible and lucrative, as PBP of selling the surplus electricity was calculated 27.2 and 54.9 years

Overall, it is concluded that investing on RSUs' installation and utilization for yielding electricity will see virtues in relation to the both economic aspect and environmental perspective. Nonetheless, embarking on domestic solar-based hydrogen production seems to require some underpinning schemes from the government like subsidies for importing equipment necessary for small-scale hydrogen generation plants.

\section{Data Availability}

All data used to support the findings of this study are included within the article. 


\section{Conflicts of Interest}

We confirm that the manuscript has been read and approved by all named authors, and there are no other persons who satisfied the criteria for authorship but are not listed. We further confirm that the order of authors listed in the manuscript has been approved by all of us.

\section{References}

[1] L. Xu, E. Long, and J. Wei, "Study on the limiting height of rooftop solar energy equipment in street canyons under the cityscape constraints," Solar Energy, vol. 206, pp. 1-7, 2020.

[2] V. Khare, S. Nema, and P. Baredar, "Optimisation of the hybrid renewable energy system by HOMER, PSO and CPSO for the study area," International Journal of Sustainable Energy, vol. 36, no. 4, pp. 326-343, 2017.

[3] S. Iryna, K. Tetiana, D. Vitalii, and K. Yevgen, "Green energy projects in households and its financial support in Ukraine," International Journal of Sustainable Energy, vol. 39, no. 3, pp. 218-239, 2020.

[4] J. Carroquino, V. Roda, R. Mustata et al., "Combined production of electricity and hydrogen from solar energy and its use in the wine sector," Renewable Energy, vol. 122, pp. 251-263, 2018.

[5] A. Atiz, H. Karakilcik, M. Erden, and M. Karakilcik, "Assessment of electricity and hydrogen production performance of evacuated tube solar collectors," International Journal of Hydrogen Energy, vol. 44, no. 27, pp. 14137-14144, 2019.

[6] S. Samsatli, I. Staffell, and N. J. Samsatli, "Optimal design and operation of integrated wind-hydrogen-electricity networks for decarbonising the domestic transport sector in Great Britain," International Journal of Hydrogen Energy, vol. 41, no. 1, pp. 447-475, 2016.

[7] A. C. Duman and Ö. Güler, "Techno-economic analysis of offgrid PV/wind/fuel cell hybrid system combinations with a comparison of regularly and seasonally occupied households," Sustainable Cities and Society, vol. 42, pp. 107-126, 2018.

[8] H. Ishaq, I. Dincer, and G. F. Naterer, "Performance investigation of an integrated wind energy system for co- generation of power and hydrogen," International Journal of Hydrogen Energy, vol. 43, no. 19, pp. 9153-9164, 2018.

[9] E. Nyholm, J. Goop, M. Odenberger, and F. Johnsson, "Solar photovoltaic-battery systems in Swedish households - selfconsumption and self-sufficiency," Applied Energy, vol. 183, pp. 148-159, 2016.

[10] P. Perera, K. Hewage, M. S. Alam, W. Mèrida, and R. Sadiq, "Scenario-based economic and environmental analysis of clean energy incentives for households in Canada: multi criteria decision making approach," Journal of Cleaner Production, vol. 198, pp. 170-186, 2018.

[11] D. B. Rahut, K. A. Mottaleb, A. Ali, and J. Aryal, "The use and determinants of solar energy by sub-Saharan African households," International Journal of Sustainable Energy, vol. 37, no. 8, pp. 718-735, 2018.

[12] N. Narayan, A. Chamseddine, V. Vega-Garita et al., "Exploring the boundaries of solar home systems (SHS) for off-grid electrification: optimal SHS sizing for the multi-tier framework for household electricity access," Applied Energy, vol. 240, pp. 907-917, 2019.
[13] S. E. Hosseini, B. Butler, and M. Abdul Wahid, "Hydrogen as a battery for a rooftop household solar power generation unit," International Journal of Hydrogen Energy, vol. 45, no. 48, pp. 25811-25826, 2020.

[14] M. Jahangiri, M. H. Soulouknga, F. K. Bardei et al., “Technoecono-environmental optimal operation of grid-wind-solar electricity generation with hydrogen storage system for domestic scale, case study in Chad," International Journal of Hydrogen Energy, vol. 44, no. 54, pp. 28613-28628, 2019.

[15] A. Maleki, F. Pourfayaz, and M. H. Ahmadi, "Design of a costeffective wind/photovoltaic/hydrogen energy system for supplying a desalination unit by a heuristic approach," Solar Energy, vol. 139, pp. 666-675, 2016.

[16] M. Jahangiri, A. Haghani, A. Alidadi Shamsabadi, A. Mostafaeipour, and L. M. Pomares, "Feasibility study on the provision of electricity and hydrogen for domestic purposes in the south of Iran using grid-connected renewable energy plants," Energy Strategy Reviews, vol. 23, pp. 23-32, 2019.

[17] M. R. Akhtari and M. Baneshi, "Techno-economic assessment and optimization of a hybrid renewable co-supply of electricity, heat and hydrogen system to enhance performance by recovering excess electricity for a large energy consumer," Energy Conversion and Management, vol. 188, pp. 131-141, 2019.

[18] H. Khorasanizadeh, K. Mohammadi, and A. Aghaei, "The potential and characteristics of solar energy in Yazd Province, Iran," Iranica Journal of Energy \& Environment, vol. 5, no. 2, pp. 173-183, 2014.

[19] A. A. Dehghan, "Status and potentials of renewable energies in Yazd Province-Iran," Renewable and Sustainable Energy Reviews, vol. 15, no. 3, pp. 1491-1496, 2011.

[20] M. Jahangiri, A. A. Shamsabadi, A. Mostafaeipour, M. Rezaei, Y. Yousefi, and L. M. Pomares, "Using fuzzy MCDM technique to find the best location in Qatar for exploiting wind and solar energy to generate hydrogen and electricity," International Journal of Hydrogen Energy, vol. 45, no. 27, pp. 13862-13875, 2020.

[21] S. Guo, Y. He, H. Pei, and S. Wu, "The multi-objective capacity optimization of wind-photovoltaic-thermal energy storage hybrid power system with electric heater," Solar Energy, vol. 195, pp. 138-149, 2020.

[22] P. Arévalo, D. Benavides, J. Lata-García, and F. Jurado, "Energy control and size optimization of a hybrid system (photovoltaic- hidrokinetic) using various storage technologies," Sustainable Cities and Society, vol. 52, p. 101773, 2020.

[23] HOMER, “The HOMER Pro ${ }^{\circledR}$ microgrid software," May 2020, http://www.homerenergy.com/.

[24] T. M. Azerefegn, R. Bhandari, and A. V. Ramayya, "Technoeconomic analysis of grid-integrated PV/wind systems for electricity reliability enhancement in Ethiopian industrial park," Sustainable Cities and Society, vol. 53, p. 101915, 2020.

[25] A. Sedaghat, A. Mostafaeipour, M. Rezaei, M. Jahangiri, and A. Mehrabi, "A new semi-empirical wind turbine capacity factor for maximizing annual electricity and hydrogen production," International Journal of Hydrogen Energy, vol. 45, no. 32, pp. 15888-15903, 2020.

[26] M. Gökçek and C. Kale, “Techno-economical evaluation of a hydrogen refuelling station powered by Wind- PV hybrid power system: a case study for İzmir-Çeşme," International Journal of Hydrogen Energy, vol. 43, no. 23, pp. 1061510625, 2018. 
[27] M. A. V. Rad, R. Ghasempour, P. Rahdan, S. Mousavi, and M. Arastounia, "Techno-economic analysis of a hybrid power system based on the cost-effective hydrogen production method for rural electrification, a case study in Iran," Energy, vol. 190, p. 116421, 2020.

[28] Z. Abdin and W. Mérida, "Hybrid energy systems for off-grid power supply and hydrogen production based on renewable energy: a techno-economic analysis," Energy Conversion and Management, vol. 196, pp. 1068-1079, 2019.

[29] M. Rezaei, M. Salimi, M. Momeni, and A. Mostafaeipour, "Investigation of the socio-economic feasibility of installing wind turbines to produce hydrogen: case study," International Journal of Hydrogen Energy, vol. 43, no. 52, pp. 23135-23147, 2018.

[30] SATBA, "Renewable energy and energy efficiency organization of Iran," March 2020, http://www.satba.gov.ir.

[31] M. Rezaei, K. R. Khalilpour, and M. Jahangiri, "Multi-criteria location identification for wind/solar based hydrogen generation: the case of capital cities of a developing country," International Journal of Hydrogen Energy, vol. 45, no. 58, pp. 3315133168, 2020.

[32] "Natural Resources Canada," March 2020, https://www.nrcan .gc.ca/sites/www.nrcan.gc.ca/files/oee/pdf/transportation/ fuel-efficient-technologies/autosmart_factsheet_6_e.pdf.

[33] "Forbes," August 2020, https://www.forbes.com/sites/ lauriewinkless/2016/06/01/are-hydrogen-fuel-cell-carsbecoming-normal/?sh=3a76b1f3683a.

[34] Yazd's Electrical Distribution CompanyAugust 2020, https:// www.yed.co.ir/.

[35] M. Rezaei, U. Dampage, B. K. Das, O. Nasif, P. F. Borowski, and M. A. Mohamed, "Investigating the impact of economic uncertainty on optimal sizing of grid-independent hybrid renewable energy systems," PRO, vol. 9, no. 8, 2021. 